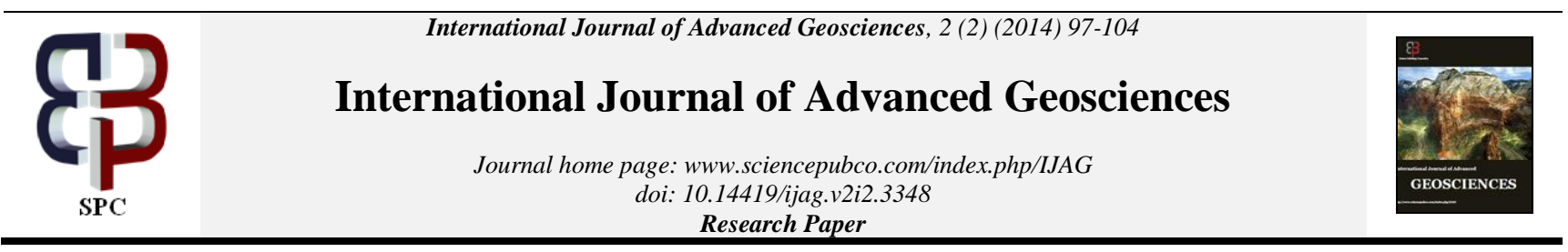

\title{
Groundwater geochemistry of shallow and deep aquifers from Jalgaon district, northern Maharashtra (India)
}

\author{
Baride M V ${ }^{1}$, Patil S N ${ }^{2}$, Golekar R B ${ }^{2 *}$ \\ ${ }^{1}$ Department of Geology, Z.B. Patil College, Dhule - 424002 (India) \\ ${ }^{2}$ Department of Applied Geology, School of Environmental and Earth Sciences, North Maharashtra University, Jalgaon (India) 425001 \\ *Corresponding author E-mail: rbgolekar@gmail.com
}

\begin{abstract}
This paper contains assessment of groundwater quality with reference to drinking and agricultural use in Jalgaon district, Northern Maharashtra (India). In present study 53 groundwater samples were collected in post monsoon (2010) and pre monsoon period (2011) from different location of Jalgaon district. Analytical results of geochemical analysis of groundwater compare with World health Organization and Indian Drinking Water Standards. Groundwater quality of study area has been deteriorated predominantly due to over exploration and anthropogenic activities.

Geochemistry of groundwater shows that the $\mathrm{Ca}>\mathrm{Mg}>\mathrm{Na}>\mathrm{K}$ and $\mathrm{HCO}_{3}>\mathrm{Cl}>\mathrm{SO}_{4}>\mathrm{CO}_{3}{ }^{2-}$ trend. Most of the groundwater samples are observed as $\mathrm{Ca}-\mathrm{HCO}_{3}$ Type. Groundwater samples of the study area show higher concentration of TDS $(>1000 \mathrm{ppm}), \mathrm{Cl}(>1000$ $\mathrm{ppm}), \mathrm{NO}_{3}(>45 \mathrm{ppm}), \mathrm{K}(>10 \mathrm{ppm}), \mathrm{Ca}(>200 \mathrm{ppm}), \mathrm{HCO}_{3}(>600 \mathrm{ppm})$ and $\mathrm{B}(<1 \mathrm{ppm})$. Irrigation water quality has been inadequately affected by salinity hazards and residual soluble carbonate (RSC).
\end{abstract}

Keywords: Groundwater Geochemistry, Shallow and Deep Aquifers, Medical Geology, Irrigation Hazards, Deccan Trap, India.

\section{Introduction}

Water quality is become one of the most important aspects in our living environment and that chemistry of groundwater has a bearing on our health and livestock. Due to insufficient availability of surface water to meet the requirement of human activities groundwater remains only option to supply the increasing demand of water. Groundwater is primarily source of water supply for drinking, agricultural and domestic to many countries and states in the world. In recent years water contamination has been recognized as one of the major issues in India. The quality of groundwater is declining due to heavy industrialization and agricultural activities. The chemical alteration of meteoric water depends upon mineral species, duration of solid water interaction, dissolution of mineral species and anthropogenic source (Fathy and Traugott, 2012).

Significance of hydrochemistry in groundwater has led to detailed studies of geochemical evolution of groundwater. The present study area water quality has been deteriorated especially in dug/bore wells mainly due to over exploitation of water and excessive use of fertilizers (Golekar, 2014). It is clear that infiltration of effluents has responsible to the contamination of aquifers. The aim of present work was assessment and investigation of groundwater geochemistry with respect to drinking and agricultural purpose from Jalgaon district, Northern Maharashtra, India.

\section{Description of the study area}

The study area is situated in Jalgaon district, Northern Maharashtra. India. Geographical coordinates of study area Latitude 20.15
$\mathrm{N}$ to $21.25 \mathrm{~N}$ and Longitude $74.55 \mathrm{E}$ to $76.28 \mathrm{E}$. Study area falls under survey of India toposheets number - $46 \mathrm{O} / 8,46 \mathrm{P} / 5,46 \mathrm{p} / 9$, $46 \mathrm{O} / 16$ and $46 \mathrm{P} / 1$. Location map of study area are shown in figure 1 .

\subsection{Geology}

Study area predominately covered by Deccan Basalts which is Cretaceous to Lower Eocene age and along river courses covers thick alluvium of Quaternary age. Different types of basaltic flows have been reported from southern part of study area. The entire area flows variation in physical characteristics there is a transition from the 'Aa' type and 'Pahoehoe' type. The basaltic flow represents a sequence of eruptions with fine grained basalt, vesicular, amygdaloidal, fractured, jointed, porphyritic and massive layers of basalts. Each flow consisting of lower is massive unit and upper vesicular basalt. Successive lava flows are separated by inter trappean red bole which is varying thickness from 0.5 to 1 meter. Northern part of study area covered by thick alluvium of Quaternary age which is silt and clay layers. Geological map of Jalgaon district has shown in figure 2.

\subsection{Geomorphology}

The drainage pattern is dendritic to sub dendritic and soil type is black cotton. The study area shows two geomorphic units viz. 1) Northern part of study area is represented by thick alluvium of Tapi River tract. The Younger and Older Alluvium are represented by interbeded layers of silt and clays with varying thickness of 70 $\mathrm{m}$. The Jalgaon, Dharangaon and Yawal block is covered by thick alluvium of silt and clay. 2) Southern part of study area exhibits 
detached hills of Deccan Trap (Erandol Block). Drainage map of the area under study has shown in figure 3 .

\subsection{Hydrometeorology}

Study area falls under semi-arid climatic zone. The average annual rainfall is about $650 \mathrm{~mm} /$ per annum. The mean maximum temperature ranges from $29.5^{\circ} \mathrm{C}$ to $48^{\circ} \mathrm{C}$ in months of May. The mean minimum temperature ranges from $12^{\circ} \mathrm{C}$ to $24^{\circ} \mathrm{C}$ in month of December- January. The high relative humidity concentration $83.63 \%$ occurs in rainy season, viz. June to October. Long term rainfall data (1998-2007) suggests decrease in rainfall 2003 to 2005 and sharp increase in 2005 and 2006 (Golekar et al. 2013).

\subsection{Hydrogeology}

Groundwater of study area occurs in deep wells under semiconfined to confined conditions due to thick pile of clay found intermittently in alluvium area. Fluctuation of water table varies from 0.5 to $8 \mathrm{M}$. Water level fluctuation in alluvium area is less than the basaltic area (Patil et al. 2010). Groundwater is an important source of water supply for agriculture in the region. Deep water level areas have been observed in parts of Daharangaon and Yawal sub district (CGWB, 2009). Groundwater occurs in weathered, vesicular, jointed and fractured basalts under unconfined condition. Northern part of study area generally drilled hand pump and open well due to shallow groundwater table. Southern part of the study area mainly in Daharangaon and Yawal sub district, groundwater level is extremely deep due to overexploitation, predominately drilled tube well used for drinking and irrigation (Golekar et al. 2013). The occurrence groundwater in the investigated area is controlled by rainfall, topography, vegetation and drainage.
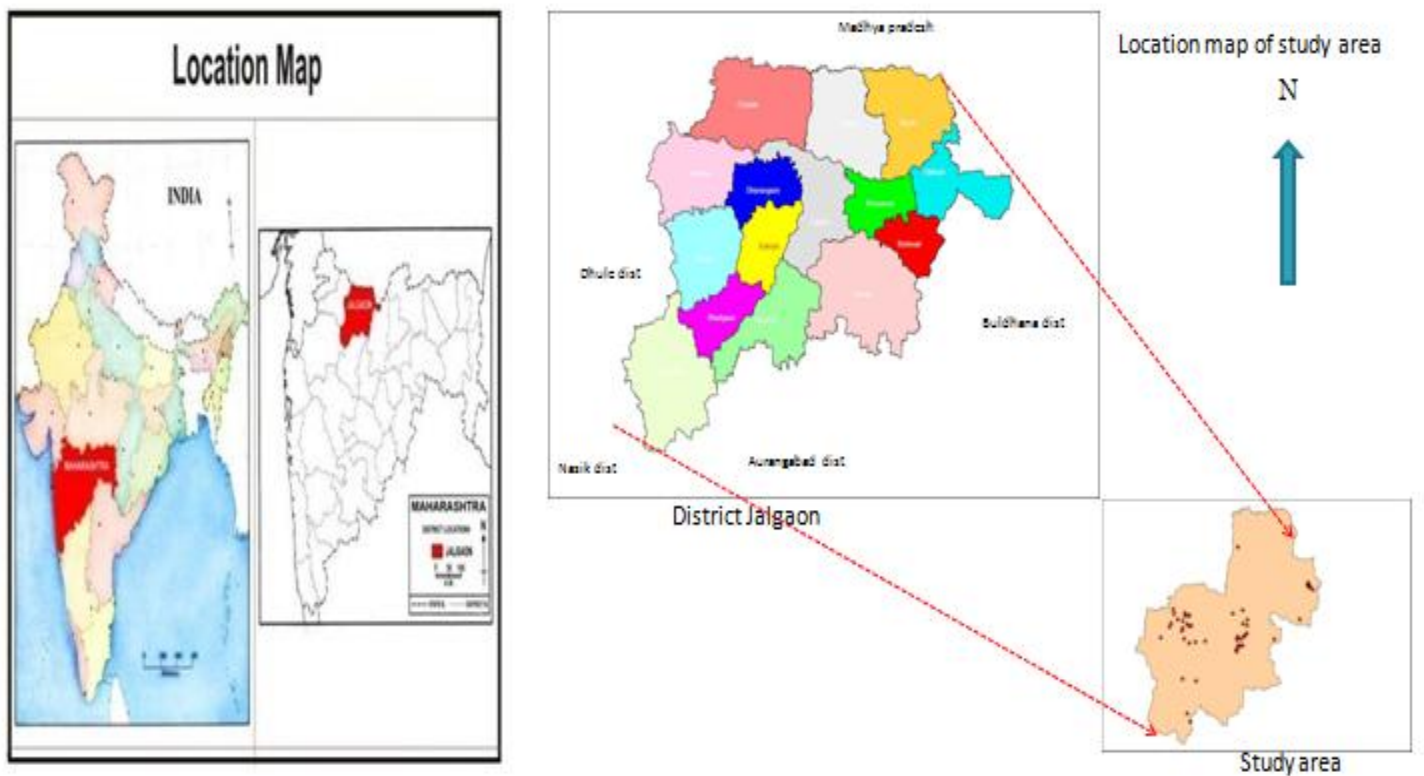

Fig. 1: Location Map of Study Area

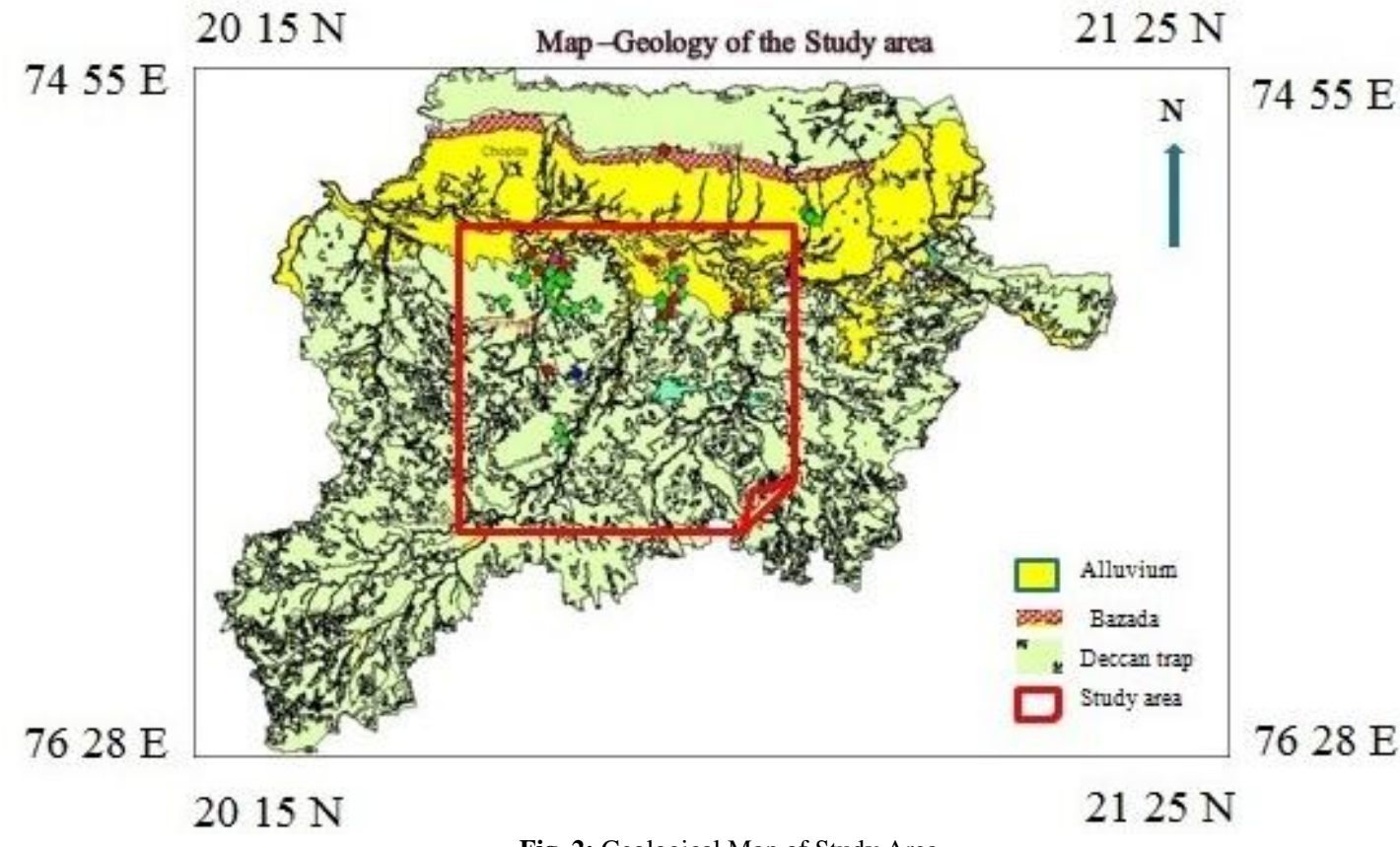

Fig. 2: Geological Map of Study Area 


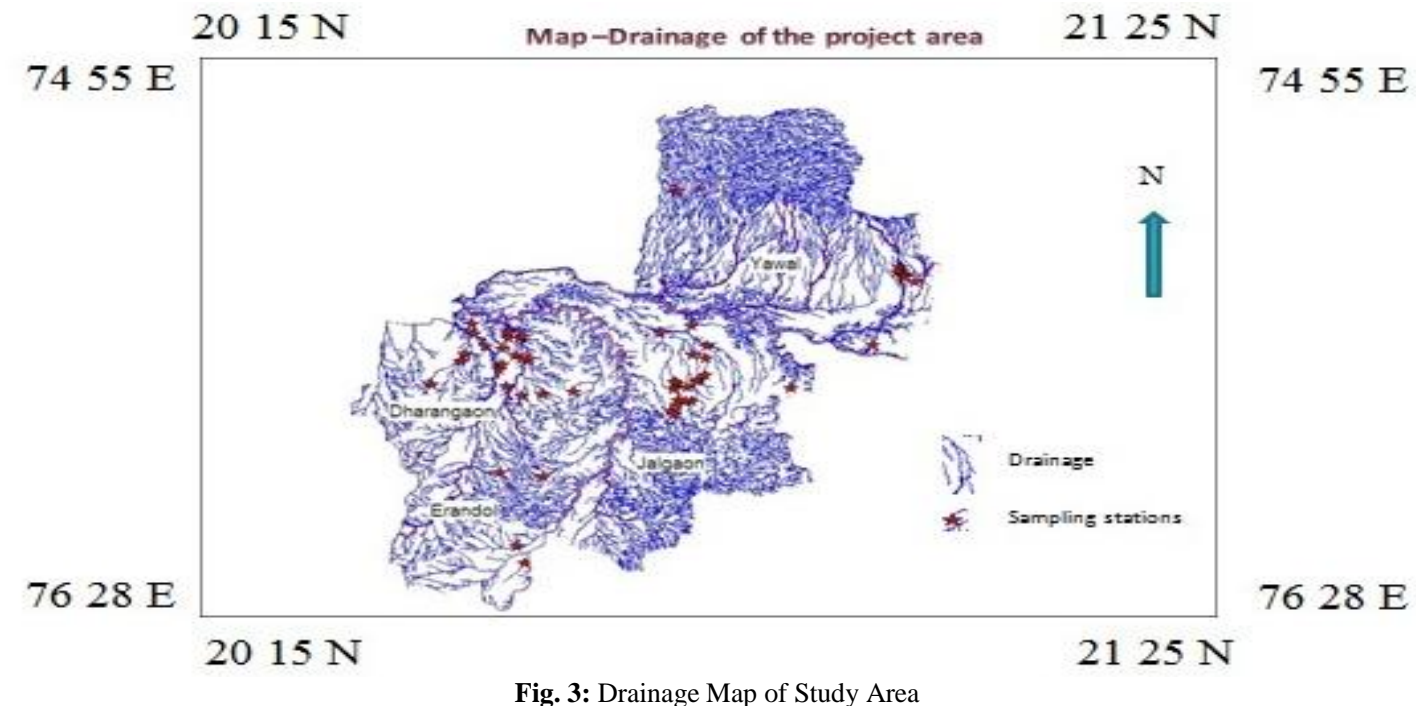

\section{Materials and methodology}

53 samples instead of shallow ( 3 to $20 \mathrm{~m}$ ) and deep aquifers (32 to $70 \mathrm{~m} \mathrm{bgl}$ ) were collected during post monsoon (December - 2010) and pre monsoon (May - 2011). Geochemical analysis of groundwater samples were carried out adopted by standard technique and procedure (APHA, 1998). $\mathrm{pH}, \mathrm{EC}$ and TDS were measured on digital water analysis kit. Total hardness and calcium determined by standard EDTA $(0.01 \mathrm{M})$ titrimetric method. Carbonate and bicarbonate determined by standard hydrochloric acid $(0.01 \mathrm{~N})$ titrimetric method. Chloride ion determined by standard silver nitrate titrimetric method. Sulphate, Nitrate and Phosphate estimation was done by the standard colorimetric method. Boron was analyzed by colorimetric method using carmine solution. Sodium, Potassium and Magnesium analyzed by double beam atomic absorption spectrometer (AAS) acetylene gas based. The precise locations of sampling points were determined in field through GPS (Global Positioning System) GARMIN and gave exact Latitude, Longitude and Altitude. A medical survey was carried out in selected villages from the area under study whereas nitrate, fluoride and total hardness were observed exceeding the BIS limits. The doctors of these villages were also contacted and enquired about the occurrence of methaenoglobinaemia (blue baby), fluorosis and kidney stones in the doubtful villages.

\section{Result and discussion}

Statistical summary of groundwater quality parameters along with BIS drinking water standards are given in Table 1.

Table 1: Statistical Summary of Groundwater Quality Parameters with BIS Drinking Water Standards

\begin{tabular}{|c|c|c|c|c|c|c|c|c|c|c|}
\hline \multicolumn{3}{|c|}{$\mathrm{n}=53$} & \multicolumn{3}{|c|}{$\begin{array}{l}\text { Post Monsoon } \\
2010 \\
\end{array}$} & \multicolumn{3}{|c|}{$\begin{array}{l}\text { Pre monsoon } \\
2011 \\
\end{array}$} & \multicolumn{2}{|c|}{ Classification } \\
\hline \multirow[t]{5}{*}{$\begin{array}{l}\mathrm{S} \\
\mathrm{r}\end{array}$} & $\begin{array}{l}\text { Cate- } \\
\text { gory }\end{array}$ & $\begin{array}{l}\text { Pa- } \\
\text { ramet } \\
\text { er }\end{array}$ & $\begin{array}{l}\mathrm{M} \\
\mathrm{ax}\end{array}$ & $\begin{array}{l}\text { M } \\
\text { in }\end{array}$ & $\begin{array}{l}\text { Av } \\
\text { g. }\end{array}$ & $\begin{array}{l}\text { M } \\
\text { ax }\end{array}$ & $\begin{array}{l}M \\
\text { in }\end{array}$ & $\begin{array}{l}\text { Avg } \\
\text {. }\end{array}$ & \multirow{2}{*}{$\begin{array}{l}\text { High- } \\
\text { est } \\
\text { De- } \\
\text { sirabl } \\
\text { e } \\
6.5- \\
8.5\end{array}$} & $\begin{array}{l}\text { Per- } \\
\text { missibl } \\
\text { e Limit }\end{array}$ \\
\hline & $\begin{array}{l}\text { Gen- } \\
\text { eral }\end{array}$ & $\mathrm{pH}$ & 8.5 & 6 & $\begin{array}{l}7.5 \\
5\end{array}$ & 8.2 & $\begin{array}{l}6 . \\
2\end{array}$ & 7.04 & & ----- \\
\hline & & EC & $\begin{array}{l}51 \\
50\end{array}$ & $\begin{array}{l}33 \\
5\end{array}$ & $\begin{array}{l}18 \\
22\end{array}$ & $\begin{array}{l}46 \\
40\end{array}$ & $\begin{array}{l}32 \\
8\end{array}$ & $\begin{array}{l}195 \\
2.4\end{array}$ & 1400 & ----- \\
\hline & & TDS & $\begin{array}{l}32 \\
40\end{array}$ & $\begin{array}{l}22 \\
0\end{array}$ & $\begin{array}{l}10 \\
40\end{array}$ & $\begin{array}{l}30 \\
30\end{array}$ & $\begin{array}{l}21 \\
6\end{array}$ & $\begin{array}{l}125 \\
7\end{array}$ & 500 & 2000 \\
\hline & & TH & $\begin{array}{l}16 \\
10\end{array}$ & $\begin{array}{l}16 \\
4\end{array}$ & $\begin{array}{l}52 \\
5.9\end{array}$ & $\begin{array}{l}15 \\
40\end{array}$ & $\begin{array}{l}12 \\
0\end{array}$ & $\begin{array}{l}501 . \\
73\end{array}$ & 300 & 600 \\
\hline \multirow{3}{*}{2} & \multirow{3}{*}{$\begin{array}{l}\text { Cati- } \\
\text { on }\end{array}$} & TA & $\begin{array}{l}10 \\
80\end{array}$ & $\begin{array}{l}15 \\
2\end{array}$ & $\begin{array}{l}52 \\
7.2\end{array}$ & $\begin{array}{l}10 \\
85\end{array}$ & $\begin{array}{l}15 \\
9\end{array}$ & $\begin{array}{l}544 . \\
4\end{array}$ & 200 & 600 \\
\hline & & $\mathrm{Ca}$ & $\begin{array}{l}43 \\
8\end{array}$ & 13 & $\begin{array}{l}10 \\
3.9\end{array}$ & $\begin{array}{l}44 \\
5\end{array}$ & 17 & $\begin{array}{l}105 . \\
25\end{array}$ & 75 & 200 \\
\hline & & $\mathrm{Mg}$ & $\begin{array}{l}56 . \\
5\end{array}$ & $\begin{array}{l}8 . \\
5\end{array}$ & $\begin{array}{l}17 . \\
66\end{array}$ & $\begin{array}{l}22 . \\
6\end{array}$ & $\begin{array}{l}6 . \\
4\end{array}$ & 15.8 & 30 & 100 \\
\hline
\end{tabular}

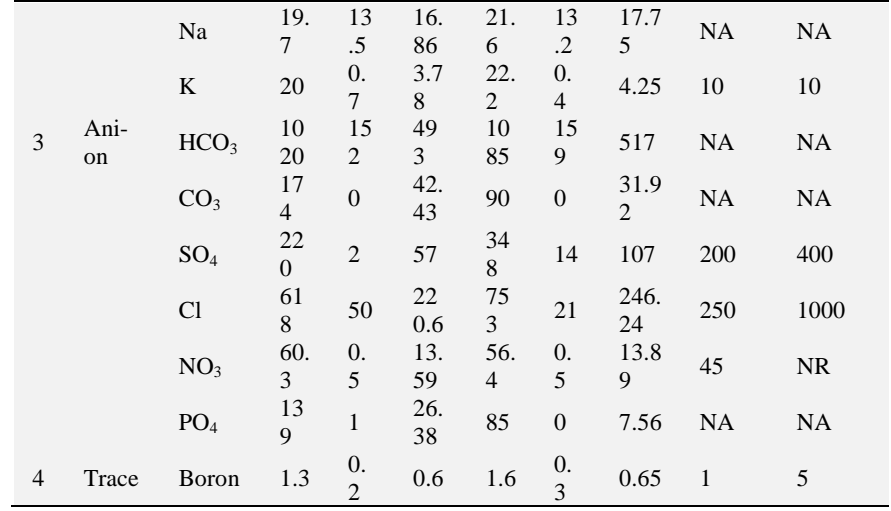

All parameter expressed in ppm Except EC in $\mu \mathrm{s} / \mathrm{cm}$ and $\mathrm{pH}$ Where, $\mathrm{n}=$ number of groundwater samples, NA = Not available

\subsection{Drinking water quality status}

$\mathrm{pH}$ was groundwater samples varies from 6.5 to 8.5 for post monsoon and pre monsoon from 6.1 to 7.7 which is alkaline.

Concentration of total hardness in study area is observed exceeds than permissible limit of BIS (BIS, 2003). Total hardness results reveal that the 80 percent groundwater samples exceed than permissible limit. In deep aquifer total hardness is high as compared to shallow aquifer. According to (Table 2) Durfor and Becker's classification of total hardness, groundwater is very hard at all locations except three sites (Burton \& Cornhill 1977).

Table 2: Durfor and Becker's Classification of Groundwater Samples Based on TH Ppm

\begin{tabular}{lllll}
\hline $\begin{array}{l}\text { Sr. } \\
\text { no. }\end{array}$ & $\begin{array}{l}\text { Classification of groundwa- } \\
\text { ter }\end{array}$ & $\begin{array}{l}\text { Hardness } \\
(\mathrm{ppm})\end{array}$ & \multicolumn{2}{l}{$\begin{array}{l}\text { No. of sam- } \\
\text { ples }\end{array}$} \\
\hline & & & SA & DA \\
1 & Soft & $0-60$ & 0 & 0 \\
2 & Moderately hard & $61-120$ & 0 & 0 \\
3 & Hard & $121-180$ & 0 & 3 \\
4 & Very hard & $>180$ & All & 27 \\
\hline
\end{tabular}

(Where, SA = Shallow Aquifer, DA = Deep aquifer)

TDS in water originates from natural sources, sewage, urban and agricultural runoff and industrial wastewater. The concentrations of total dissolved solid for post monsoon in shallow aquifer range from 414 to $3240 \mathrm{ppm}$ and in deep aquifer 220 to $2390 \mathrm{ppm}$. The concentrations of pre monsoon is in shallow aquifer 467 to 3030 ppm and deep aquifer 216 to $2490 \mathrm{mg} /$. Desirable limit of TDS is $500 \mathrm{ppm}$ and maximum permissible limit is $1400 \mathrm{ppm}$ as per BIS, if TDS above $2100 \mathrm{ppm}$ it is not suitable for any purpose. According to TDS limit of BIS, 80 and 90 percent samples for post monsoon and pre monsoon season respectively above desirable limits. In the present study out of 53 samples, 17 groundwater 
samples are unsuitable for drinking and irrigation purpose. In early studies, contrary relationships were reported between TDS concentrations in drinking water and the incidence of cancer and cardiovascular disease (Burton \& Cornhill 1977; Sauer, 1974). The groundwater samples were classified regarding TDS (Table 3). Most of the groundwater is fresh and suitable for drinking purposes based on TDS (Rabinove et al. 1958).

Table 3: Rabinove and Et Al Classification of Groundwater Samples Based on TDS (Pp

\begin{tabular}{llll}
\hline $\begin{array}{l}\text { Sr. } \\
\text { No. }\end{array}$ & $\begin{array}{l}\text { Classification of } \\
\text { groundwater }\end{array}$ & $\begin{array}{l}\text { Total dissolved salts } \\
(\mathrm{ppm})\end{array}$ & $\begin{array}{l}\text { No. of sam- } \\
\text { ples }\end{array}$ \\
\hline 1 & Non-saline & $<1000$ & 27 \\
2 & Slightly saline & $1000-3000$ & 25 \\
3 & Moderately saline & $3000-10000$ & 1 \\
4 & Very saline & $>10000$ & Nil \\
\hline
\end{tabular}

Calcium concentration in shallow aquifer is more as compared to deep aquifers. Calcium ion concentration in groundwater samples in pre monsoon period is exceeds than post monsoon indicates the overexploitation of water from subsurface in summer season. Natural source of the calcium in groundwater may be cause of calcite plagioclase feldspar minerals and zeolite cavities in basaltic rock of investigated area. The average abundance of $\mathrm{Ca}$ in earth crust in basaltic rocks about 77600 ppm (Konrad \& Dennis 1994). They may cause of high concentration of this element in groundwater. Magnesium ion concentration in all water samples of investigated area is within permissible limits of BIS for drinking water standards $(30 \mathrm{ppm})$. Magnesium ion concentration in groundwater slightly increases in pre monsoon period as compared to post monsoon period because of overexploitation. Sodium concentration is insignificant in all water samples of both seasons.

Potassium concentration in study area observed exceeds than permissible limit of BIS (Ravikumar \& Venkatesharaju 2010). Sample number 1, 4 and 5 for post monsoon and 1, 2, 4, 5, 41, 47 and 48 for pre monsoon period potassium exceeds than desirable limit of drinking water standards as per BIS limit.

Total alkalinity concentration for post monsoon in shallow aquife varies from 125 to $750 \mathrm{ppm}$ and deep aquifer from 125 to 900 ppm. The pre monsoon total alkalinity concentration in shallow aquifer varies from 130 to $640 \mathrm{ppm}$ and deep aquifer from 120 to $825 \mathrm{ppm}$. In investigated study area 90 percent samples are above the permissible limit of alkalinity as per BIS drinking water standard.

Chloride concentration range varies from 67 to $618 \mathrm{ppm}$ for pos monsoon in shallow aquifer and deep aquifer is 50 to $589 \mathrm{ppm}$. In the post monsoon shallow aquifer range is 78 to $753 \mathrm{ppm}$ and deep aquifer is 21 to $703 \mathrm{ppm} .30 \%$ water samples of post monsoon and $60 \%$ water samples of pre monsoon season not safe for drinking because it exceeds than the desirable limit whereas desirable limit of chloride for drinking water is about $250 \mathrm{ppm}$ (BIS 2003). The average abundance of $\mathrm{Cl}$ in earth crust in the basaltic rocks about $200 \mathrm{ppm}$ (Konrad \& Dennis 1994]. Chloride in groundwater from both factors they may be natural or anthropogenic such as run-off, use of inorganic fertilizers, septic tank effluents, animal feeds, industrial effluents and irrigation drainage Bicarbonate concentration of post monsoon in groundwater varies from 152 to 1020 and pre monsoon varies from 159 to $1085 \mathrm{ppm}$. Nitrate concentrations occur in groundwater samples ranges from 0.3 to $63.4 \mathrm{ppm}$ of the study area. The nitrate level in water samples from study area 6 and 10 percent of post monsoon and pre monsoon respectively exceeds than permissible limit of drinking water standards where limit is 45 ppm (BIS, 2003). Higher concentration of nitrate in groundwater they may be extreme use of nitrogen fertilizers, human and animal wastes (Janardhana et al. 2009). Jalgaon district is $3^{\text {rd }}$ rank for the use of chemical fertilizers in India. High nitrate concentration in drinking water causes infant of methaenoglobinaemia widely known as Blue baby disease.

Sulphate concentrations below $4 \mathrm{meq} / \mathrm{l}$ is very excellent, 4 to 7 $\mathrm{meq} / \mathrm{l}$ is good, 7 to $12 \mathrm{meq} / \mathrm{l}$ is permissible 12 to 20 in doubtful and above 20 is unsuitable (James et al. 1982). In the current study area most of the groundwater samples are under excellent category except one site (sample no. 48/ pre monsoon 2011) above permissible limit of sulphate ion as per BIS limits.

Boron in drinking water more than $1 \mathrm{ppm}$ it is not considered to human consumption. The excessive amount of boron can affect the central nervous system (APHA, 1998). Boron concentration in the study area observed varies from 0.7 to $1.3 \mathrm{ppm}$ (limit of 1.0 ppm, BIS, 2003). Some shows boron concentration more than 1 ppm in shallow aquifer (post monsoon). The average abundance of Boron in earth crust is about $12 \mathrm{ppm}$ but high in basalts rocks about $15 \mathrm{ppm}$ they may be one cause of boron in groundwater of area under study. Phosphate in groundwater recognized to increase application of fertilizers in agricultural sectors.

Phosphorous addition to the water bodies even in small amount can be produced growth of algae and aquatic vegetation they may be causing eutrophication of the aquatic system (Handa, 1990). The phosphorus is also content in various minerals (Hamilton, 1992). Phosphate has been reported in groundwater by several investigators (Raju, 1979; Shriniwas \& Rajendra Prasad 1997; Mondal et al. 2005). The present study area covered by basaltic rocks mainly composed of pyroxene, plagioclase minerals. Pyroxene and plagioclase minerals having 89 and $25 \mathrm{ppm}$ phosphorus content respectively (Konrad \& Dennis 1994). Phosphorous in the groundwater is observed range from 1.00 to $139.00 \mathrm{ppm}$ for post monsoon and 0.00 to $85 \mathrm{ppm}$ for pre monsoon which is beyond the permissible limits in few exceptional sites of the study area. Some ground samples of the study area phosphorous level is high due to excessive use of fertilizer in form of NPK 15:15:15, 18:18:10, 10:26:26 and superphosphate.

\subsection{Irrigation water quality status}

Assessment and suitability of groundwater for the irrigation purpose is calculated based on TDS, electrical conductivity, Kelly's ratio, residual sodium carbonate, permeability Index, Na percentage, corrosivity ratio and $\mathrm{Mg}$ ratio. Statistical summary of Irrigation water quality parameters and characteristic ratios are given in table 4 .

Table 4: Statistical Summary of Irrigation Parameters and Characteristic Ratios

\begin{tabular}{lllll}
\hline Irrigation parameter & Season & Maximum & Minimum & Average \\
\hline SAR & post & 0.7 & 0.2 & 0.4 \\
SAR & pre & 0.7 & 0.2 & 0.4 \\
RSC & post & 14.3 & -16.6 & 2.3 \\
RSC & Pre & 14 & -18.6 & 2.2 \\
MR & post & 147.2 & 9.3 & 42.8 \\
MR & Pre & 122.5 & 7.2 & 40.1 \\
Na \% & post & 114.8 & 6.2 & 26 \\
Na \% & pre & 102.2 & 6.5 & 26.6 \\
CAI 1 & post & 17.4 & 0.9 & 5.9 \\
CAI 1 & pre & 21.1 & -0.7 & 6.6 \\
CAI 2 & post & 17.3 & 1.3 & 6 \\
CAI 2 & pre & 21.1 & 0.3 & 6.7 \\
CR & post & 2.8 & 0.1 & 0.5 \\
CR & pre & 4 & 0.1 & 0.7 \\
KR & post & 0.5 & 0 & 0.2 \\
KR & pre & 0.5 & 0 & 0.2 \\
\hline
\end{tabular}

Where, SAR $=$ Sodium Adsorption ratio, $\mathrm{RSC}=$ Residual soluble carbonate, $\mathrm{Na} \%=$ Sodium percentage, $\mathrm{CAI} \mathrm{I}=$ Chloro alkaline indices I, CAI $\mathrm{II}=$ Chloro alkaline indices II, $\mathrm{CR}=$ Corrosivity ratio, $\mathrm{KR}=$ Kelly's ratio)

\subsubsection{Electrical conductivity (salinity hazards)}

Electrical conductivity is a good measurement of salinity hazard to crops as it reflects the TDS in groundwater. The EC concentration for post monsoon in shallow aquifer varies from 618 to 3240 $\mu \mathrm{s} / \mathrm{cm}$ and deep aquifer 335 to $3690 \mu \mathrm{s} / \mathrm{cm}$. The EC concentration of pre monsoon period in shallow aquifer ranges from 703 to 3030 $\mu \mathrm{s} / \mathrm{cm}$ and deep aquifer ranges from 328 to $3740 \mu \mathrm{s} / \mathrm{cm}$.

According to Mondal, water has been classified for irrigation purpose point of view as (1) Fresh $(<1500 \mu \mathrm{s} / \mathrm{cm})$, (2) Brackish $(1500-3000 \mu \mathrm{s} / \mathrm{cm})$ and (3) Saline (>3000 $\mu \mathrm{s} / \mathrm{cm})$ (Mondal et al. 2005). Based on these classification water samples of the study area each group clearly shows 50 percent samples in post mon- 
soon and 45 percent sample in pre monsoon were fresh quality, 40 percent sample in post monsoon and 35 percent samples in pre monsoon were brackish nature. In the study area 10 percent sample for the post monsoon and 15 percent samples for the period of pre monsoon fall under the saline water category.

\subsubsection{Sodium adsorption ratio (SAR)}

SAR is express as per Richards (Richard, 1954),

$\mathrm{SAR}=\mathrm{Na} / \sqrt{ }[(\mathrm{Ca}+\mathrm{Mg}) / 2]$

Where all ionic concentration expressed in meq/l

Table 5 shows classification of water with reference to the SAR (Raghunath, 1987). If SAR concentration is less than 10 water is excellent for irrigation suggest that the all samples of post monsoon and pre monsoon fall under the excellent category.

Table 5: Classifications of Sodium Adsorption Ratio

\begin{tabular}{|c|c|c|c|c|c|}
\hline \multirow[t]{2}{*}{$\begin{array}{l}\text { SAR } \\
\text { Ratio }\end{array}$} & \multirow[t]{2}{*}{ Water quality } & \multicolumn{2}{|c|}{$\begin{array}{l}\text { Post Monsoon } \\
\text { (2010) } \\
\text { No of samples }\end{array}$} & \multicolumn{2}{|c|}{$\begin{array}{l}\text { Pre Monsoon } \\
\text { (2011) } \\
\text { No of samples }\end{array}$} \\
\hline & & SA & DA & SA & $\mathrm{DA}$ \\
\hline 0-06 & Excellent & 23 & 30 & 23 & 30 \\
\hline 06-09 & $\begin{array}{l}\text { Increasing Prob- } \\
\text { lem }\end{array}$ & Nil & Nil & Nil & Nil \\
\hline$>10$ & Serve Problem & Nil & Nil & Nil & Nil \\
\hline
\end{tabular}

(Where, $\mathrm{SA}=$ Shallow aquifer, $\mathrm{DA}=$ Deep aquifer)

\subsubsection{Residual sodium carbonate (RSC)}

The RSC is calculated as per Eaton (1950),

$$
\mathrm{RSC}=\left(\mathrm{CO}_{3}+\mathrm{HCO}_{3}\right)-(\mathrm{Ca}+\mathrm{Mg})
$$

Where all ionic concentration expressed in meq/l The groundwater having excess of $\mathrm{CO}_{3}{ }^{-}$and $\mathrm{HCO}_{3}{ }^{-}$concentration over the $\mathrm{Ca}^{++}$and $\mathrm{Mg}^{++}$in excess of limits and there are unfavorably effects on agriculture (Raghunath, 1987; Eaton, 1950). The RSC concentrations for shallow aquifer (post monsoon) ranges from -16.56 to 11.78 , concentrations for pre monsoon ranges from -18.6 to 9.35 and deep aquifer (Post monsoon) ranges from -6.54 to 14.33 and pre monsoon it ranges from -8.70 to 13.98 . Lloyd and Heathcote (1985) have classified irrigation water based on RSC as suitable $(<1.25)$, marginal (1.25 to 2.5$)$ and not suitable $(>2.5)$. Accordingly the shallow aquifer is excellent quality but deep aquifer is not suitable to irrigation because of its RSC concentration > 2.5 .

\subsubsection{Magnesium ratio}

MR is express as,

$\mathrm{MR}=(\mathrm{Mg} \times 100) /(\mathrm{Ca}+\mathrm{Mg})$

Where all ionic concentration expressed in meq/l

Magnesium ratio observed in groundwater sample range from 9.26 to 147.2 for post monsoon, 7.21 to 122.5 for pre monsoon period. If the concentration of magnesium ratio less than 50 it is suitable to irrigation purpose (Pandian \& Sankar 2007). In study area 35 percent samples of the post monsoon and 30 percent samples of pre monsoon is higher than $50 \%$ MR shows unsuitable to irrigation purposes.

\subsubsection{Sodium percentage $(\mathrm{Na} \%)$}

Sodium concentration is an important measure for defining the type of irrigation. The Sodium percentage is calculated as per Doneen (1962),

Sodium $\mathrm{Na} \%=(\mathrm{Na} \times 100) /(\mathrm{Ca}+\mathrm{Mg})$

Where all ionic concentration expressed in meq/l

Sodium percentage in shallow aquifer (post monsoon) varies from $6.19 \%$ to $36.78 \%$ and deep aquifer is 8.83 to 114.75 . Shallow aquifer (pre monsoon) varies from 6.45 to 40.05 and deep aquifer is 8.35 to 102.16 . According to $\mathrm{Na} \%$ groundwater has classified as excellent $(<20 \%)$, good $(20 \%-40 \%)$ and permissible $(40 \%-$ $60 \%$ ) some doubtful $(60 \%-80 \%)$. The Na \% in sample no. 23,29 and 31 from deep aquifer was not suitable to irrigation.

Wilcox has proposed a method for rating irrigation waters is used, based on percent sodium and electrical conductivity (Wilcox, 1955). The diagram consists of five distinct areas such as excellent to good, good to permissible, permissible to doubtful, doubtful to unsuitable and unsuitable. Total 53 groundwater samples analyzed their hydrochemistry out of 85 percentage samples belonging to excellent, good to excellent and good to permissible type during post monsoon but 80 percent of samples in pre monsoon seasons fall in excellent, excellent to good, good to permissible types. The remaining samples are doubtful to unsuitable types in both seasons of study area.

SAR (Sodium Adsorption Ratio) is an important parameter for determining suitability of groundwater to irrigation because it is a measure of alkali / sodium hazards to crops (Richard, 1954). Kumaresan and Riyazuddin (2006) have discussed their results using Wilcox diagram. Wilcox plot by SAR values versus electrical conductivity of groundwater. Wilcox plots shows that the 60 percent of post monsoon and 70 percent of pre monsoon groundwater samples falls in field of $\mathrm{C} 3 \mathrm{~S} 1$, indicating high salinity and low SAR water. While 30 percent sample of post monsoon and 25 percent samples of pre monsoon season falls in field C4S1, indicating very high salinity and low SAR which is not suitable to irrigation. Wilcox diagram shows in figure 4 and 5 for post monsoon and pre monsoon season respectively.

\subsubsection{Corrosivity ratio $(C R)$}

Corrosivity ratio expressed as,

$\mathrm{CR}=\left(\mathrm{Cl}+\mathrm{SO}_{4}\right) / 2\left(\mathrm{HCO}_{3}+\mathrm{CO}_{3}\right)$

Where all ionic concentration expressed in meq/l

If $\mathrm{CR}$ concentration is greater than 1 , their effect of corrosion leads to loss in carrying capacity of pipes (Pandian \& Sankar 2007). In post monsoon season samples number 43,44 and pre monsoon season $43,44,45,46,47$ and 48 have CR more than 1 which suggests the unsafe zone remaining all samples are showing concentrations less than 1 that is safe zone. When high concentrations of chloride occurred in water that promotes the corrosion of metal pipes because chloride increases the electrical conductivity of water and thus increase its corrosivity. In metal pipes, chloride reacts with metal ions to form soluble salts. In lead pipes, a defensive oxide layer is built up, but chloride enhances galvanic corrosion (Gregory, 1990). 


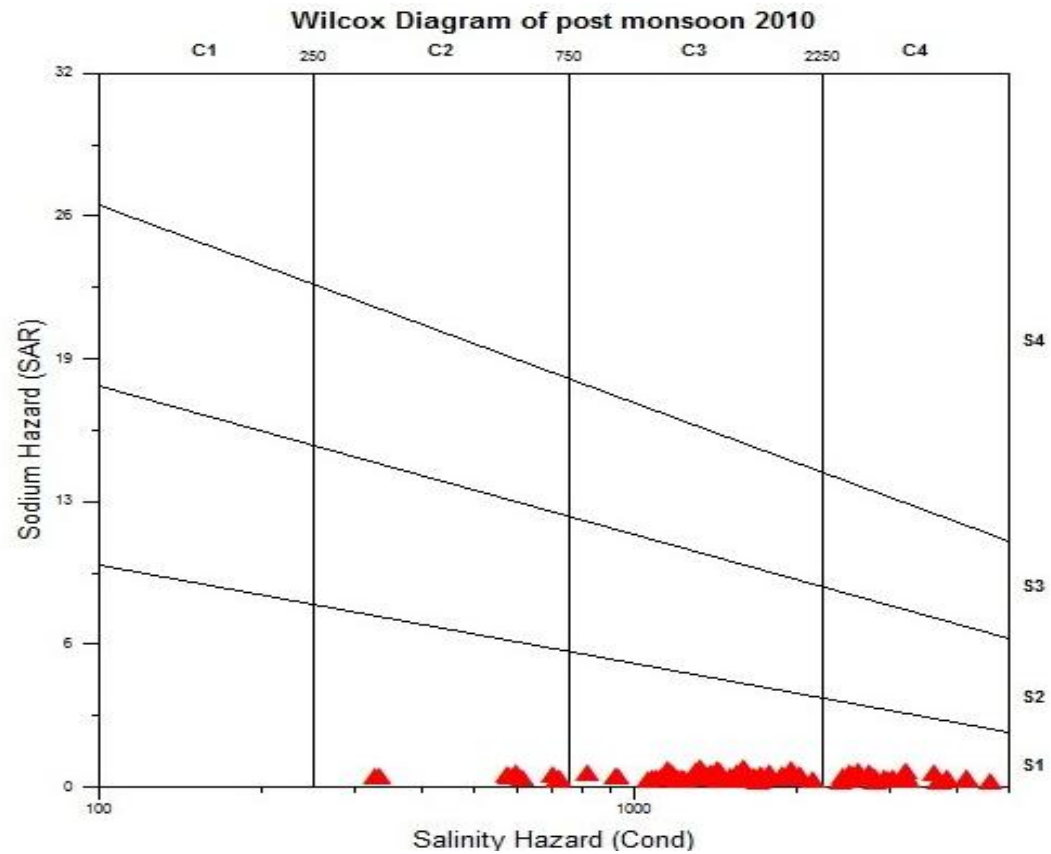

Fig. 4: Wilcox Diagram of Post Monsoon Groundwater

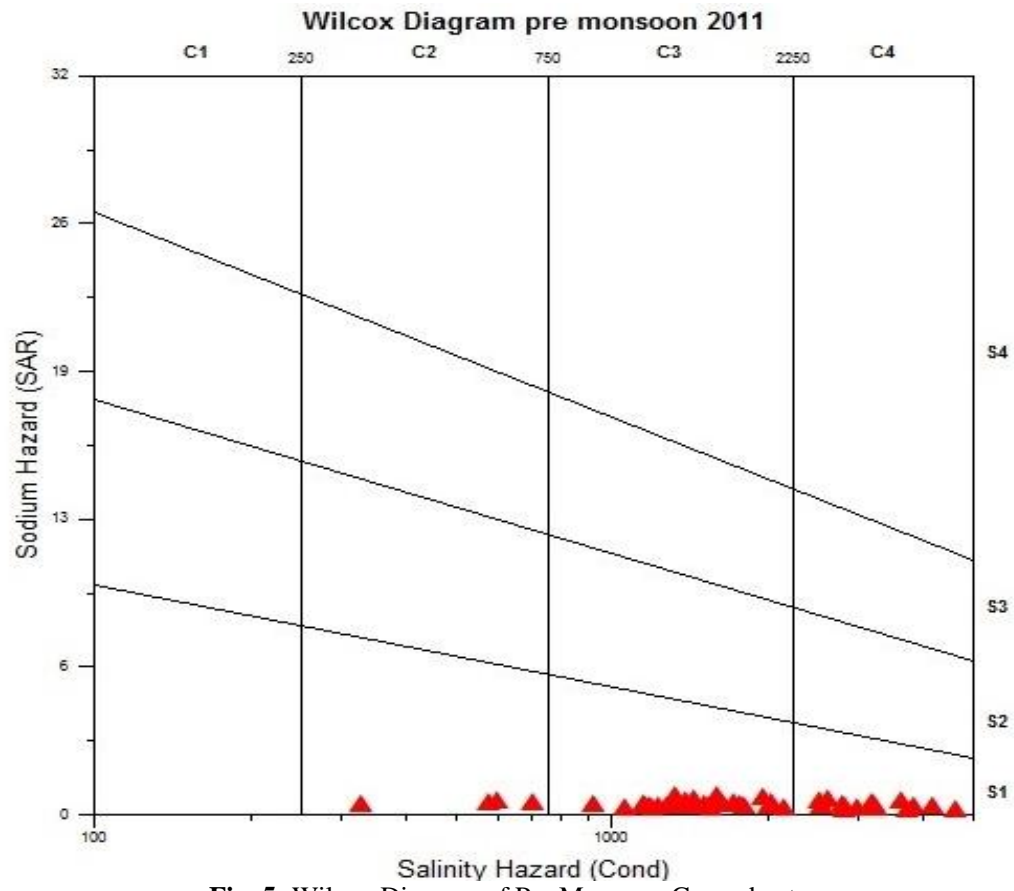

Fig. 5: Wilcox Diagram of Pre Monsoon Groundwater

\subsubsection{Kelly's ratio (KR)}

Kelly's ratio is expressed as,

Kelly's Ratio $=\mathrm{Na} /(\mathrm{Ca}+\mathrm{Mg})$

Where all ionic concentration expressed in meq/l

If $\mathrm{KR}$ is greater than 1water is not suitable to irrigation and its cause's alkali hazards to soil (Karnath, 1987). All groundwater samples of the study area Kelly's ratio shows less than 1 suggesting suitable for the irrigation.

\subsubsection{Boron hazards}

Boron is a necessary element for plant development. Boron is essential in relatively small amounts but greater than needed it becomes toxic. For some crops, if $0.2 \mathrm{ppm}$ boron in water is essential but 1 to $2 \mathrm{ppm}$ may be toxic. Boron classification for irrigation water quality as per Doneen, it gives in table 6 (Doneen,

1962). Study area water falls under the Class I and II type of water.

(6)

\begin{tabular}{llll}
\hline Class of Irrigation water & Class I & Class II & Class III \\
\hline Concentration of Boron & $<0.5$ & 0.5 to 2.00 & $>2.00$ \\
Boron classification in the & $\mathrm{ppm}$ & $\mathrm{ppm}$ & $\mathrm{ppm}$ \\
study area & $30 \%$ & $70 \%$ & $0 \%$ \\
\hline
\end{tabular}

\subsection{Characteristic of groundwater chemistry}

\subsubsection{Chloro alkaline indices}

The ion exchange between the groundwater and its surroundings during residence or travel can be understand by studying the Chloro alkaline Indices expressed as (Schoeller, 1977),

$\mathrm{CAI}-\mathrm{I}=\mathrm{Na}+\mathrm{K} / \mathrm{Cl}$

$\mathrm{CAI}-\mathrm{II}=[\mathrm{Cl}-(\mathrm{Na}+\mathrm{K})] /\left[\mathrm{SO}_{4}+\mathrm{HCO}_{3}+\mathrm{CO}_{3}+\mathrm{NO}_{3}\right]$ 
Where all ionic concentration expressed in meq/l

According to Schoeller all samples are negative ratio indicating Base Exchange. Whereas, the Base Exchange positive concentrations are sign of the reaction is chloroalkaline equilibrium and negative concentrations are sign of chloroalkaline is disequilibrium.

\subsubsection{Hydro chemical facies of groundwater}

Classification of groundwater with reference to hydrochemical processes by using piper diagram (Piper, 1953). Piper diagram has shown in figure 6 and 7 for post monsoon and pre monsoon respectively. It shows that the most of analysed groundwater samples falls in the field of $\mathrm{Ca}-\mathrm{HCO}_{3}$ and $\mathrm{Ca}-\mathrm{Cl}-\mathrm{HCO}_{3}$ water types shows that the alkaline earth metals $\left(\mathrm{Ca}^{++}+\mathrm{Ma}^{++}\right)$exceeds than alkali metals $\left(\mathrm{Na}^{+}+\mathrm{K}^{+}\right)$and weak acid anions $\left(\mathrm{CO}_{3}+\mathrm{HCO}_{3}\right)$ exceeds than strong acid $\left(\mathrm{Cl}+\mathrm{SO}_{4}^{-2}\right)$ strong acid anions.

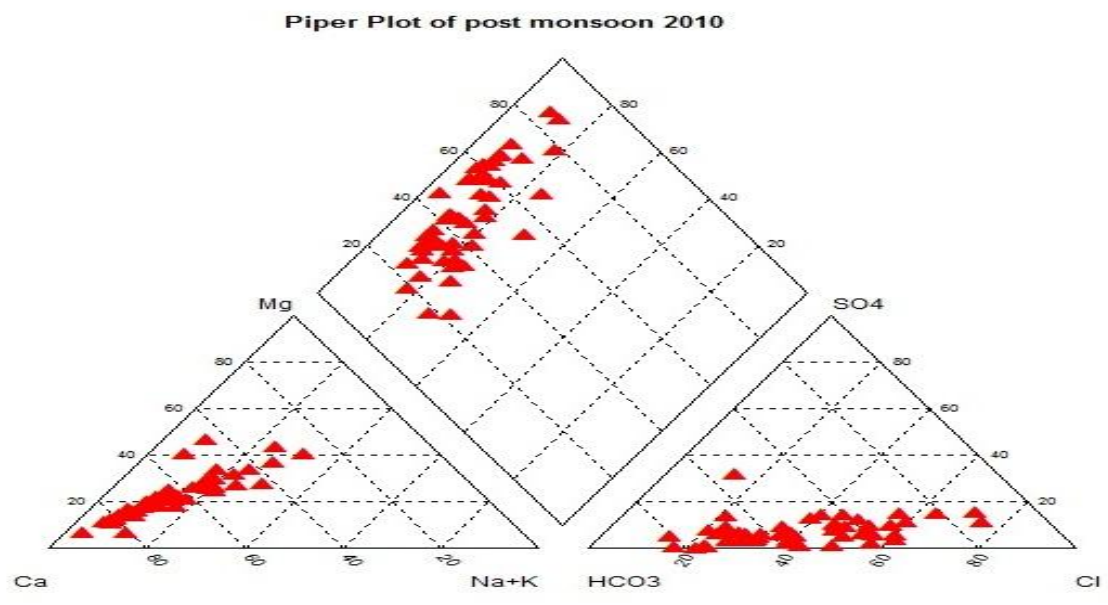

Fig. 6: Piper Trilinear Diagram of Post Monsoon Groundwater

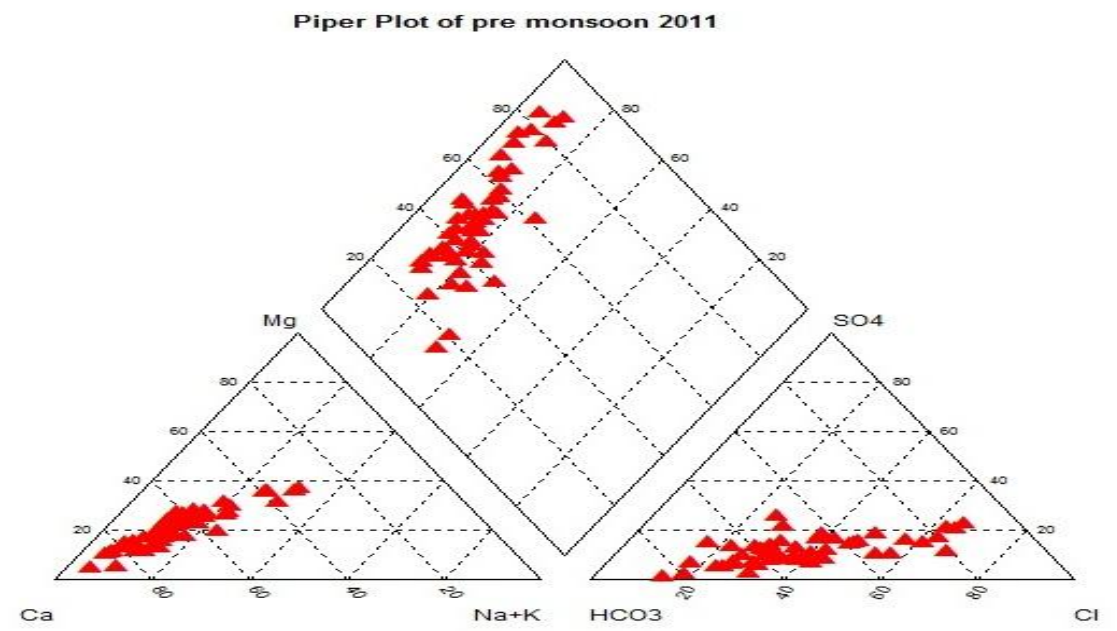

Fig. 7: Piper Trilinear Diagram of Pre Monsoon Groundwater

\section{Summary and conclusions}

Groundwater of the study area shows alkaline earth (ca and mg) exceeds than alkalis ( $\mathrm{Na}$ and $\mathrm{K})$, weak acids $\left(\mathrm{HCO}_{3}\right)$ exceeds than strong acids $\left(\mathrm{Cl}, \mathrm{SO}_{4}\right.$ and $\left.\mathrm{NO}_{3}\right)$. The $\mathrm{Ca}, \mathrm{Mg}$ and $\mathrm{HCO}_{3}$ indicate hardness is dominated by the alkaline earth and weak acids. The geochemistry of the groundwater of the study area shows $\mathrm{Ca}>\mathrm{Mg}$ $>\mathrm{Na}>\mathrm{K}$ and $\mathrm{HCO}_{3}>\mathrm{Cl}>\mathrm{SO}_{4}>\mathrm{CO}_{3}^{2-}$ trends. Hence groundwater from the study area shows dominant of calcium bicarbonate. The water increases its major ions and electrical conductivity in pre monsoon period as compared to post monsoon period due to over exploitation of groundwater. The homogeny in the quality of groundwater from the shallow and deep aquifers in study area, it has been observed concentration of major ion and physical parameter like EC and TDS concentrations in shallow aquifer is higher than deeper aquifer. Higher concentration of $\mathrm{NO}_{3}$ in some samples indicates anthropogenic pollution due to the excessive use of nitrogenous fertilizers in highly cultivated areas seems responsible for high concentrations.
Although the majority of people affected due to water borne diseases by anthropogenic or geogenic those are live in rural area consume the water without treatment. They are depend on untreated plants, lakes, rivers, surface water or tube wells they may be contamination and its impact on human health.

Groundwater quality of the study area mainly affected due to anthropogenic activities and overexploitation of groundwater for agricultural practices. The study area facing problem of salinity, this is impact of excessive withdrawn of groundwater. In general the boron is low in the fresh water however high in brackish and saline water. Boron observed in the groundwater indicators of salinity, entire study area 20 percent samples observed the saline nature because of EC > $3000 \mu \mathrm{mohs} / \mathrm{cm}, \mathrm{B}>700 \mu \mathrm{g} / \mathrm{l}$ and $>1500$ ppm TDS. The calculated parameter of irrigation water quality like SAR, Kelly's ratio, RSC and sodium percentage shows that groundwater can be used for irrigation without any hazards but RSC trends are increasing in the area which doubtful.

From the medical survey in the area under study revealed that the no medical report on methaenoglobinaemia and dental fluorosis disease was observed. The drinking water source of few villages 
having high values of total hardness in the groundwater samples was probability to have harmful effects like kidney stones and other related diseases. The villagers were surveyed for these kidney stones and a rare incidence was reported.

\section{Recommendations}

Whereas, high concentrations of TDS (>500 ppm), Cl (> 250 ppm) and $\mathrm{NO}_{3}(>45 \mathrm{ppm})$ restrict the direct use of water for the drinking purposes. Portability of drinking water is mainly based on recommended guidelines of permissible limit for certain parameter as per BIS 2003. When water contamination exceeds than the permissible limit it is unfit for human consumption. All ions in groundwater samples increasing trends of pre monsoon as compared to post monsoon period they may be cause of excessive withdrawn of groundwater.

\section{Acknowledgements}

The financial assistance in the form of Major Research Project (SR/S4/ES-328/2008), awarded to one of the author (MVB) by Department of Science and Technology (DST) Govt. of India, New Delhi is thankfully acknowledged. The co-operation of North Maharashtra University officials is also acknowledged.

\section{References}

[1] APHA (1998) Standard methods for the examination of water and waste water, 19th edition APHA, Washington DC, USA

[2] BIS (2003) Drinking Water Standards (IS: 1050091 revised 2003)

[3] Burton A. C., Cornhill JF. (1977) Correlation of cancer death rates with altitude and with the quality of water supply of the 100 largest cities in the United States Journal of toxicology and environmenta health 3(3): 465-478

[4] CGWB (2009) Jalgaon district profiles

[5] Doneen, L. D. (1962) the influence of crop and soil on percolating waters. Proceeding of 1961 Biennial Conference on Groundwater Recharge pp 156-163

[6] Eaton E. M. (1950) Significance of carbonate in irrigation water soil science 69: 123-133

[7] Fathy, Abdalla, and Traugott, Scheytt (2012) Hydrochemistry of surface water and groundwater from a fractured carbonate aquifer in the Helwan area, Egypt. J. Earth Syst. Sci. v. 121 (1), pp 109-124 http://dx.doi.org/10.1007/s12040-012-0140-7.

[8] Golekar R. B., Baride M.V., Patil S. N. (2013) Human health risk due to trace elements contamination in groundwater from Anjani and Jhiri river catchment of Northern Maharashtra, India Earth Science Research Journal 17(1): 17-23

[9] Golekar R B, Baride M V and Patil S. N. (2013) Groundwater appraisal of shallow and deep aquifers from Anjani and Jhiri river Catchment, Northern Maharashtra India SRTMU's Research Journal of Science 2(2) pp 118 - 129

[10]Golekar R. B., Baride M. V., Patil S. N. (2014) Geomedical health hazard due to groundwater quality from Anjani - Jhiri River Basin, Northern Maharashtra (India) International Research Journal of Earth Sciences Vol. 2 (1), pp 1-14

[11]Gregory R. (1990) galvanic corrosion of lead solder in copper pipe work. Journal of Water and Environmental Management 4 (2):112 118 http://dx.doi.org/10.1111/j.1747-6593.1990.tb01566.x.

[12]Hamilton (1992) Effect of fertilizer on groundwater quality in India In symposium on groundwater development A perspective for the year 2000 A.D. University of Roorke India pp 451-462

[13]Handa (1990) Contamination of groundwater by phosphate Bhujal News 5 pp 24-36

[14]James, D.W., R.J. Hanks, and J.J. Jurinak (1982) Modern Irrigated Soils. John Wiley \& Sons, New York, NY.

[15]Janardhana \& et al (2009) Groundwater quality in lower varuna River basin, Varanasi, district Uttar Pradesh Jour. Geol. Soc. India 73: 178 $192 \mathrm{http} / / / \mathrm{dx}$.doi.org/10.1007/s12594-009-0074-0.

[16]Karnath K.R. (1987) Groundwater Assessment Tata McGraw hill Publishing Co. Ltd New Delhi.

[17]Konrad \& Dennis (1994) Textbooks of Introduction to Geochemistry 3rd edition Published by MC Graw Hill INC
[18]Kumaresan, M. and P. Riyazuddin (2006) Major ion chemistry of environmental samples around suburban of Chennai city Current Sci. 91 (12): $1668-1677$

[19]Lloyd J.W. and Heathcote J.A. (1985) Natural Inorganic Hydrochemistry in Relation to Groundwater Claredon Press, Oxford.

[20]Mondal, N. C., Saxena, V. K., and Singh, V. S. (2005) Assessment of groundwater pollution due to tannery industries in and around Dindigul, Tamilnadu, India Environmental Geology 48 (2) : 149-157 http://dx.doi.org/10.1007/s00254-005-1244-z.

[21]Pandian K. and Sankar K. (2007) Hydro geochemistry and groundwater quality in the vaippar River Basin Tamilnadu, Journal of Geological Society of India 69: 970-982.

[22]Patil, S. N., Rokade, V. M., Patil, Sandeep P., Patil Sachin., and Jagadale Shantaram (2010) Hydrogeochemical Investigation of Groundwater from Faizpur area of Jalgaon District, Maharashtra, Journal of Applied Geochemistry 12 (2): 217-223.

[23]Piper A. M. (1953) A graphic procedure in the geochemical interpretation of water analysis. Report of the United States Geological Survey.

[24] Rabinove C.L. and et al (1958) Saline water resources of North Dakota, US Geog. Sur. Water Supply Paper 142872.

[25] Raghunath (1987) Groundwater Wiley Eastern Ltd. Delhi India

[26]Raju (1979) Operation Anantapur GSI India Miscellaneous publication.

[27]Ravikumar P. and Venkatesharaju K. (2010) Major ion chemistry and hydrochemical studies of groundwater of Bangalore South Taluk, India Environ Monit. Assess 163: 643-653 http://dx.doi.org/10.1007/s10661-009-0865-1.

[28]Richard L.A. (1954) Diagnosis and Improvement of Saline and Alkali Soils. U.S. Department of Agriculture Handbook.

[29]Sauer HI (1974) Relationship between trace element content of drinking water and chronic disease In: Trace metals in water supplies: occurrence, significance and control. University of Illinois bulletin 71(108):39.

[30]Schoeller H. (1977) Geochemistry of groundwater in groundwater studies An International Guide for Research and practices UNESCO Paris.

[31] Shriniwas and Rajendra Prasad (1997) Phosphate pollution in the groundwater of lower Vamsadhara River basin India Environmental Geology31 (1/2): 117-722.

[32]Wilcox L.V. (1955) Classification and use of irrigation waters USDA, Circular 969, and Washington, DC, USA. 